\title{
The management of pain: non-pharmacologic analgesia
}

\author{
Patrizia Papacci, Francesca Serrao, Mikael Ghennet Tesfagabir, Velia Purcaro, Carmen Giannantonio, \\ Costantino Romagnoli
}

From XXI Congress of the Italian Society of Neonatology

Palermo, Italy. 24-26 September 2015

\begin{abstract}
"Pain is an unpleasant sensory and emotional experience associated with actual or potential tissue damage, or described in terms of such damage. Each individual learns the application of the word through experiences related to injury in early life"[1]. It is now clear that premature and full-term newborns have the neuroanatomical pathways from the periphery to cortex required for nociception. In fact by the 23th week of gestation painful stimuli are associated with physiologic, hormonal, and metabolic markers of the stress response. Indeed pain perception may be greater because of immaturity of descending inhibitory pathways [2]. Preterm infants are particularly vulnerable to brief and long term effects of pain and stress because system modulating sensory experience is immature[3,4]. Neonatal intensive care involves a high number of diagnostic and therapeutic procedures which are associated with pain for preterm and sick newborn infants. In addition to immediate unpleasantness, painful experiences can imprint themselves indelibly on the nervous system amplifying and causing typically painless sensations to be experienced as pain. Pharmacological and non-pharmacological intervention (NFI) are recommended for painprevention and pain management [5]. In order to achieve optimum efficacy, both pharmacological and NFI additionally require a reduction of external stimuli, such as loud noise and bright light [6]. NFI is recommended for procedural and mild pain [7]. NFI for procedural pain is a treatment that is initiated before and during the procedure in order to reduce the physiological consequences of nociceptive transmission provoked by the procedure. Therefore NFI could be considered a "pre-emptive analgesia". NFI activate the "gate control mechanism",
\end{abstract}

\footnotetext{
* Correspondence: p.papacci@rm.unicatt.it

Department of Pediatrics, Division of Neonatology, Catholic University of Sacred Heart, Rome00168, Italy
}

some intervention lead to an endogenous endorphin dispersal which contributes to modulation of the pain pulse at the level of spinal cord $[8,9]$, some other may elicit activation of neuropeptides systems that can achieve an analgesic effect through the potentiation of opioid activity [10], There is sufficient evidence to support the use of NFI, particularlybreast feeding, sweet-tasting solutions, kangaroo care, non nutritive suckling, swaddling and facilitate touching for the common needle-puncture procedures [11-13]. Other NFI such as music, olfactory and multisensory stimulation areto some degree beneficial to neonates who undergo painful procedures $[14,15]$. Despite our limited understanding of the underlying mechanisms of actions of NFI, there seems to be few documented short-term harms from their use. NFI need a collaborative effort. Support from the administration and leadership, both formal and cultural, is crucial for the implementation of NFI[16].

\section{Published: 24 September 2015}

\section{References}

6(3):247-248

2. Lee SJ, Ralston HJ, Drey EA, Partridge JC, Rosen MA: Fetal pain: a systematic multidisciplinary review of the evidence. JAMA 2005, 294:947-54.

3. Beggs S, Fitzgerald M: Development of peripheral and spinal nociceptive systems. In Pain in neonates and infants. 3 edition. Edinburgh (United Kingdom): Elsevier;Anand KJ, Stevens BJ, McGrath PJ 2007:11-24.

4. Vinall J, Steven PM, Chau V, Brummelte S, Synnes AR, Grunau RE: Neonatal pain in relation to postnatal growth in infants born very preterm. Pain 2012, 153:1374-1381

5. American and Canadian Academy of Pediatrics: Prevention and management of pain and stress in the neonate. Pediatrics 2000, 15:454-461.

6. Stevens B, Gibbins S, Franck L: Treatment of pain in the neonatal intensive care unit. PediatrClin North Am 2000, 3(47):633-650. 
7. Anand KJS: International evidence-based group for neonatal pain. Consensus statement for the prevention and management of pain in the newborn. Arch PediatrAdolesc Med 2001, 155:173-180.

8. Melzack R, Wall PD: Pain mechanism: a new theory. Science 1965, 150(699):971-979.

9. Gradin M, Schollin J: The role of endogenous opioids in mediating pain reduction by orally administrated glucose among newborns. Pediatrics 2005, 115(4):1004-1007.

10. Hebb AL, Poulin JF, Roach SP, Zacharko RM, Drolet G: Cholecystokinin and endogenous opioid peptides: interactive influence on pain, cognition, and emotion. Prog Neuropsychopharmacol Biol Psychiatr 2005, 29:1225-1238.

11. Stevens B, Yamada J, Ohlsson A: Sucrose for anlgesia in newborn infants undrgoin painful procedures. Cochrane Database Syst Rev 2010, 1: CD001069.

12. Harrison D, Beggs S, Stevens B: Sucrose for procedural pain management in infants. Pediatrics 2012, 130(5):918-925.

13. Bellieni CV, Tei M, Coccina F, Buonocore G: Sensorial saturation for infants' pain. J Matern Fetal Neonatal Med 2012, 25(Suppl 1):79-81.

14. Cignacco E, Hamers JP, Stoffel L, Van Lingen RA, Gessler P, McDougall J, Nelle M: The efficacy of non-pharmacological interventions in the management of procedural pain in preterm and term neonates. A systematic literature review. Eur J Pain 2007, 11(2):139-152.

15. Pillai Riddell RR, Racine NM, Turcotte K, Uman LS, Horton RE, Din Osmun L, et al: Non-pharmacological management of infant and young child procedural pain. Cochrane Database Syst Rev 2011, 10: CD006275.

16. McNair C, Campbell Yeo M, Johnston C, Taddio A: Nonpharmacological management of pain during common needle puncture procedures in infants: current research evidence and practical considerations. Clin Perinatol 2013, 40(3):493-508.

doi:10.1186/1824-7288-41-S1-A27

Cite this article as: Papacci et al.: The management of pain: non-

pharmacologic analgesia. Italian Journal of Pediatrics 2015 41(Suppl 1):A27.

\section{Submit your next manuscript to BioMed Central and take full advantage of:}

- Convenient online submission

- Thorough peer review

- No space constraints or color figure charges

- Immediate publication on acceptance

- Inclusion in PubMed, CAS, Scopus and Google Scholar

- Research which is freely available for redistribution

Submit your manuscript at www.biomedcentral.com/submit
Biomed Central 